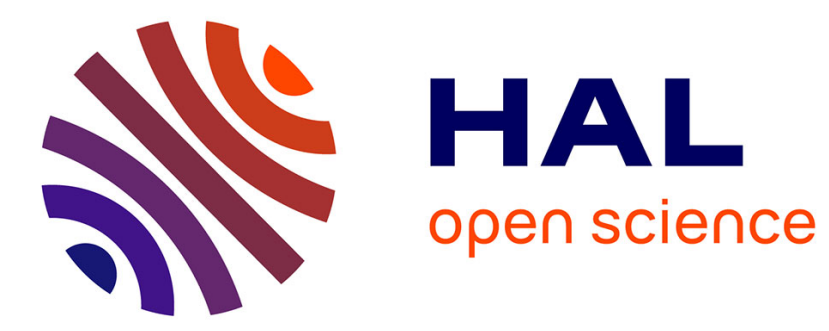

\title{
A study of the tribological behavior of duplex treatment
}

Ahcene Siad, Corinne Nouveau, Aurélien Besnard, Philippe Jacquet, Jean

Quesada

\section{To cite this version:}

Ahcene Siad, Corinne Nouveau, Aurélien Besnard, Philippe Jacquet, Jean Quesada. A study of the tribological behavior of duplex treatment. Annales de Chimie - Science des Matériaux, 2015, 39 (3-4), pp.201-208. 10.3166/acsm.39.201-208 . hal-01327208

\section{HAL Id: hal-01327208 \\ https://hal.science/hal-01327208}

Submitted on 15 Feb 2017

HAL is a multi-disciplinary open access archive for the deposit and dissemination of scientific research documents, whether they are published or not. The documents may come from teaching and research institutions in France or abroad, or from public or private research centers.
L'archive ouverte pluridisciplinaire HAL, est destinée au dépôt et à la diffusion de documents scientifiques de niveau recherche, publiés ou non, émanant des établissements d'enseignement et de recherche français ou étrangers, des laboratoires publics ou privés. 


\title{
A STUDY OF THE TRIBOLOGICAL BEHAVIOR OF DUPLEX TREATMENT
}

\author{
Ahcene SIAD ${ }^{\mathrm{a}}$, Corinne NOUVEAU ${ }^{\mathrm{a}}$, Aurélien BESNARD ${ }^{\mathrm{a}}$, Philippe JACQUET ${ }^{\mathrm{a}}$, Jean QUESADA ${ }^{\mathrm{a}}$
}

Arts et Metiers ParisTech, LaBoMaP, 71250 Cluny France.

\begin{abstract}
The objective of this study was to determine the influence of duplex treatments on tribological behavior of a common used steel material. The carbide and carbonitride coatings are deposited by dual RF magnetron sputtering on carburized and carbonitrided $18 \mathrm{CrMo} 4$ steel substrates respectively. The low-pressure carburized and carbonitrided samples present 0.72 and 0.69 wt. \% carbon content at their surface respectively and a hardness of about $720 \mathrm{HV}_{0.1}$. Tribological tests were performed by a Pin-on-Disk rotative tribometer with $\mathrm{Al}_{2} \mathrm{O}_{3}$ and $100 \mathrm{Cr} 6$ balls. A comparison of the friction coefficient and the wear rate for each sample has been made. The adhesion of the coatings has been determined by analyzing the wear track by optical profilometry and microscopy. The best tribological performances were observed by combining carbides coatings and carburized $18 \mathrm{CrMo} 4$. In contrast, the TiWCN film completely delaminated.
\end{abstract}

Résumé - Etude d'un traitement duplex sur le comportement tribologique. L'objectif de cette étude est de déterminer l'influence de traitements duplex sur le comportement tribologique d'un acier couramment utilisé. Les revêtements ont été obtenus par pulvérisation RF dual magnétron. Les carbures ont été déposés sur un acier cémenté et un témoin. Les carbonitrures ont été déposés sur un acier carbonitruré et un témoin. La teneur en carbone en surface est de 0,72 et $0,69 \%$ en masse pour la cémentation et la carbonitruration respectivement. Les essais tribologiques ont été effectués avec un tribomètre rotatif bille-disque en utilisant des billes d' $\mathrm{Al}_{2} \mathrm{O}_{3}$ et de $100 \mathrm{Cr} 6$. L'adhérence des revêtements a été déterminée par analyse de la piste d'usure en utilisant la profilométrie et la microscopie optique. Les meilleures performances tribologiques ont été observées en combinant les carbures TiWC avec un acier cémenté. En revanche, le film mince de TiWCN s'est complètement délaminé.

\section{INTRODUCTION}

The duplex treatments (also called properties gradient treatments) are based on a thermochemical treatment followed by a coating deposition. The coating improves the contact fatigue, the coefficient of friction, the wear resistance, etc. On one hand, the thermochemical treatment allows a piece to bear a stressed underlayer. On the other hand, a gradient of properties (hardness, stress...) at the interface coating/substrate improves the adhesion of the coating [1]. Previous studies showed the efficiency of these treatments, for example nitrided steel tools coated with $\mathrm{TiN}, \mathrm{Cr}_{2} \mathrm{~N}$ [2] or TiN/TiAlN [3]. Besides, other researchers showed that a $\mathrm{CrN}$ duplex treatment was more efficient to protect casting molds, especially against thermal shocks, than TiN

Tirés-à-part : A. SIAD, LaBoMaP, Arts et Metiers ParisTech, 71250 Cluny, France. 
duplex treatments [4]. A best behavior of a CrN duplex treatment compared to a TiN duplex treatment in friction against X155CrMoV13-1 steel balls has been found [5].

This study deals with the influence of thermochemical treatments (low pressure carburizing and carbonitriding) on the adhesion of TiWC and TiWCN coatings deposited by dual RF magnetron sputtering. Results are presented as follows: characterization of the reference and treated steel, characterization of the coatings, and finally tribological analysis.

\section{EXPERIMENTAL DETAILS}

\subsection{Material}

All substrates are cut from a cylindrical bar (diameter $=40 \mathrm{~mm}$ ) of DIN $18 \mathrm{CrMo} 4$ (No. 1.7243). This steel is suitable for the thermochemical treatments used in this study. The samples were mechanically polished with $\mathrm{SiC}$ abrasive papers (P800) in order to reduce their roughness to $\mathrm{R}_{\mathrm{a}}=60 \pm 5 \mathrm{~nm}$. Before treatments (else thermochemical, nor deposition) they were ultrasonically cleaned with acetone $(95 \%)$ and ethanol $(96 \%)$.

\subsection{Thermochemical treatments}

The carburizing and carbonitriding treatments are conducted in a low pressure BMI furnace. After reaching the working pressure of $10 \mathrm{mbar}$ in the chamber, the temperature increased to $900^{\circ} \mathrm{C}$ and $850^{\circ} \mathrm{C}$ (carburizing and carbonitriding respectively). The diffusion treatment atmospheres are composed of ethylene $\left(\mathrm{C}_{2} \mathrm{H}_{4}\right)$ and a gas mixture of ethylene and ammonia $\left(\mathrm{NH}_{3}\right)$. After 2 hours, the samples are quenched under 5 bar of nitrogen, and annealed at $200^{\circ} \mathrm{C}$ during 2 hours under vacuum. Finally they are cooled in the furnace under a 1 bar $\mathrm{N}_{2}$ atmosphere. The carbon content at the surface of the samples was measured with a spark emission spectrometer (Jobin Yvon $32 \mathrm{E}$ ).

\subsection{Coatings deposition}

TiWC and TiWCN coatings were deposited with a dual RF magnetron sputtering system (Nordiko 3500) using a 4" Ti target (purity of $99.99 \%$ ) and a 4" WC target (purity of $99.5 \%$ ). The targets-to-substrate distance is about $160 \mathrm{~mm}$. The angles between the targets normal and the substrate normal are $+30^{\circ}$ and $-30^{\circ}$ with respect to the horizontal. The deposition conditions were determined in previous studies [6]. The working pressure was fixed to $0.8 \mathrm{~Pa}$. The TiWC coatings were deposited with a $80 \% \mathrm{Ar}+20 \% \mathrm{CH}_{4}$ gas mixture and the TiWCN coatings with a $60 \%$ $\mathrm{Ar}+30 \% \mathrm{~N} 2+10 \% \mathrm{CH} 4$ gas mixture. The voltage of the tungsten carbide and titanium targets was 400 and $-800 \mathrm{~V}$ respectively. Deposition time was $240 \mathrm{~min}$ for both coatings. TiWC coatings were deposited on carburized and reference steel samples, while TiWCN coatings were deposited on carbonitrided and reference steel. The surface morphology, cross-section observations, chemical composition and thickness of the coatings were determined by an optical microscope, a SEM with an EDX probe and an optical profilometer.

\subsection{Tribological tests}

The tribological properties of the reference, carburized and carbonitrided steel, of the TiWC and TiWCN coatings were studied using a rotative pin-on-disk tribometer (CSM HT1000). The tests were performed with a linear speed of $2 \mathrm{~cm} . \mathrm{s}^{-1}$, a constant normal load of $1 \mathrm{~N}$, a sliding radius $\mathrm{R}=4 \mathrm{~mm}$ and for a distance of $200 \mathrm{~m}$. The tests were carried out in dried atmosphere and at room temperature. These parameters were fixed on the basis of previous studies [7]. The counterparts were alumina balls $\left(\mathrm{H}=1650 \mathrm{HV}, \mathrm{R}_{\mathrm{a}}=195 \pm 7 \mathrm{~nm}\right.$ and a radius of $\left.6 \mathrm{~mm}\right)$ and $100 \mathrm{Cr} 6$ steel balls 
$\left(\mathrm{H}=700-900 \mathrm{HV}, \mathrm{R}_{\mathrm{a}}=253 \pm 6 \mathrm{~nm}\right.$ and a radius of $\left.6 \mathrm{~mm}\right)$. According to Archard's equation [8], the wear rate $\mathrm{k}$ of the track can be calculated by equation (1):

$$
k=\frac{v}{F_{N}}
$$

Where $V=2 \pi R A V$ is the wear volume $\left(\mathrm{mm}^{3}\right)$ calculated by the cross-sectional area (A) of the worn tracks and the sliding radius R. $F_{N}$ and $d$ are the normal load $(\mathrm{N})$ and the sliding distance $(\mathrm{m})$, respectively. The resultant wear tracks and wear debris were observed and analyzed by SEM and EDX. The dimensions of the wear tracks (depth and width) were measured by optical profilometry. For the wear of the balls, the basic hypothesis is that the worn volume is a perfect spherical cap.

\section{RESULTS AND DISCUSSION}

\subsection{Carburizing and carbonitriding}

The reference steel is characterized by a low carbon content $(0.24 \pm 0.03 \mathrm{wt}$ \% \%). Its structure is composed by ferrite and pearlite (figure $l$ a) and presents a hardness of $205 \pm 5 \mathrm{HV}$.
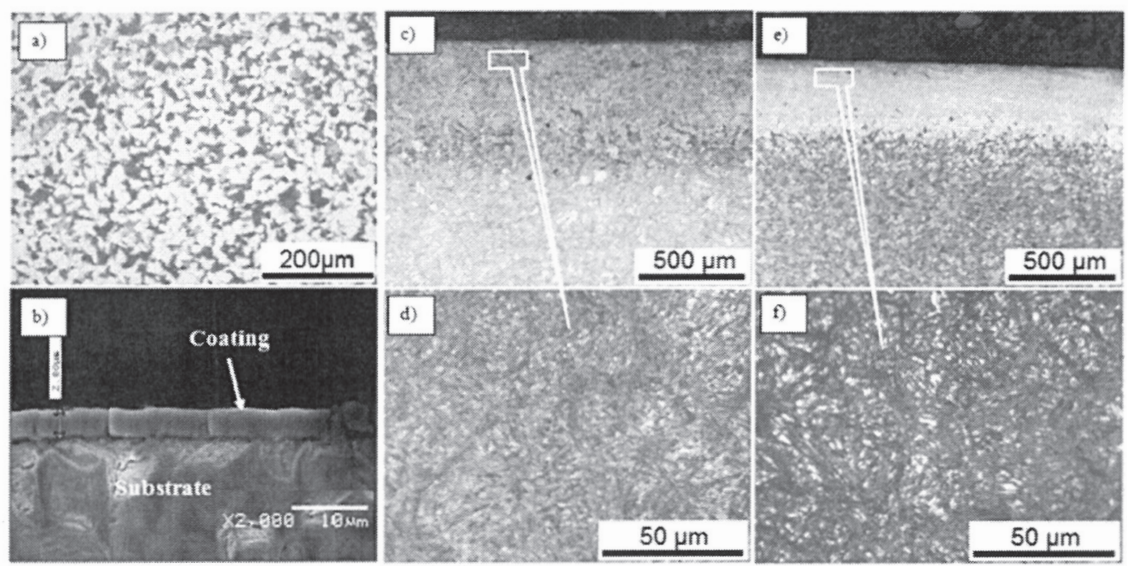

Figure 1. (a) Optical image of the reference steel, (b) SEM cross section observation of a duplex treated steel, (c) (d) optical images of the cross section of a carburized steel, (e) (f) optical images of the cross section of a carbonitrided steel.

After carburizing, the surface samples was enriched by carbon up to $0.73 \pm 0.01$ wt. $\%$. The microstructure of carburized steels is composed of plate martensite, cementite and retained austenite (figure $1 c-d$ ). These structures allow a major increase of the surface hardness [9]. A transition zone (lamellar martensite and pro-eutectoid ferrite) between the carbon-enriched layer $(\approx 540 \mu \mathrm{m}$ thick $)$ and the bulk material is observed. The steel core remains unchanged since it is not affected by the diffusion of carbon. For carbonitriding, the martensitic layer presents simultaneously carbon $(0.70 \pm$ 0.01 wt. \%) and nitrogen $\left(<0.1\right.$ wt. \%), not sufficient to form iron nitrides $\left(\mathrm{Fe}_{4} \mathrm{~N}: \% \mathrm{~N} \geq 5.3\right.$ wt. \%, $\mathrm{Fe}_{2-3} \mathrm{~N}: \% \mathrm{~N} \geq 7.25$ wt. \% [11]). Nevertheless, their presence increases the hardness of the steel and reduces the thickness of the treated layer $(\approx 380 \mu \mathrm{m}$ thick, figure 1 e $)$. We distinguish also the presence of retained austenite (white) (figure $1 \mathrm{f}$ ). Its presence is undesired for a component under solicitations [10]. Figure $1 \mathrm{~b}$ shows the cross-section of a duplex treated steel sample. This configuration ensures a gradient of properties between the coating and the substrate $[12,13]$. 
XRD patterns show four diffraction peaks that correspond to martensite $\left(\alpha\right.$ ' ICDD $-\mathrm{N}^{\circ} 00$ 006-0696, tetragonal structure) for both thermochemical treatment (carburizing and carbonitriding: $51.97^{\circ}-(110), 76.15^{\circ}-(200), 99.07^{\circ}-(211)$ and $\left.123.37^{\circ}-(220)\right)$. One can also observe the (111) at $50.88^{\circ}$ and $(220)$ at $88.92^{\circ}$ diffraction peaks corresponding to the retained austenite phase in the case of carbonitriding ( $\gamma$ : ICDD $-\mathrm{N}^{\circ} 00-052-0513$, face-centered cubic). This point confirms that the nitrogen introduced into the austenite promotes the appearance of the retained austenitic phase which is observed by optical microscopy (figure $1 \mathrm{f}$ ).

Figure 2 shows the hardness profiles obtained for carburized and carbonitrided samples.

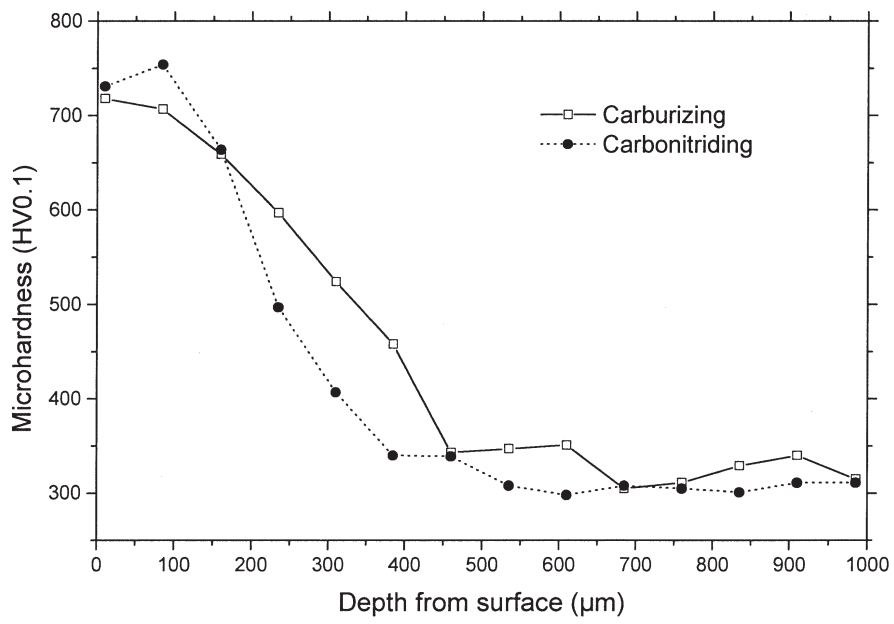

Figure 2. Microhardness profiles of the carburized and carbonitrided samples.

Three different zones are observed. They match with those observed by optical microscopy. The first zone corresponds to the outer layer that presents a high hardness ( $\mathrm{HV}=718 \pm 15$ for carburizing and $\mathrm{HV}=731 \pm 15$ for carbonitriding). It can be explained by the formation of the martensite phase during the treatment. The second zone corresponds to the diffusion region; the decrease in the case of carburizing is sharper than in the carbonitriding case. The slope of the hardness decrease depends on the carbon diffusion in the steel substrates [14]. In the third zone, the hardness remains constant and corresponds to the steel substrate hardness after treatment (HV $=313$ $\pm 15)$, higher value than the reference due the thermal treatments.

\subsection{TiWC and TiWCN coatings}

The physico-chemical and mechanical properties of TiWC and TiWCN are shown in table I.

Table I. Coatings properties.

\begin{tabular}{|c|c|c|c|c|c|c|c|c|c|c|}
\hline \multirow{2}{*}{ Coating } & \multicolumn{5}{|c|}{ Chemical composition (wt. \%) } & \multirow{2}{*}{$\begin{array}{l}\text { Thickness } \\
\qquad(\mu \mathrm{m})\end{array}$} & \multirow{2}{*}{$\begin{array}{c}\text { Hardness } \\
\text { (GPa) }\end{array}$} & \multirow{2}{*}{$\begin{array}{c}\text { Young's } \\
\text { modulus } \\
(\mathrm{GPa})\end{array}$} & \multirow{2}{*}{$\begin{array}{c}\mathrm{H}^{3} / \mathrm{E}^{2} \text { ratio } \\
\text { (GPa) }\end{array}$} & \multirow{2}{*}{$\begin{array}{l}\text { Deposition } \\
\text { rate } \\
\left(\mathrm{nm} \cdot \mathrm{min}^{-1}\right)\end{array}$} \\
\hline & $\mathrm{Ti}$ & W & $\mathrm{C}$ & $\mathrm{O}$ & $\mathrm{N}$ & & & & & \\
\hline & & & & & & & & $205.5 \pm 20$ & & \\
\hline 160 & 22.8 & 4.6 & 38.6 & 1.6 & 32.4 & 3.42 & & -...- & & 14 \\
\hline
\end{tabular}


As clearly seen, the amount of nitrogen in the gas mixture increases the deposition rate. The Young's modulus and hardness of TiWC $(2.8 \mu \mathrm{m}$ thick) are $205.5 \pm 20 \mathrm{GPa}$ and $16.6 \pm 1.2 \mathrm{GPa}$ respectively. The $\mathrm{H}^{3} / \mathrm{E}^{2}$ ratio is $0.11 \pm 0.002 \mathrm{GPa}$. Similar results were obtained by Candido [15]. Since the C/Ti ratio of TiWC coating is 0.56 , the presence of a sub-stoechiometric phase corresponding to $\mathrm{TiC}_{0.6}$ could be assumed $[16,17$, and 18].

The XRD patterns of the TiWC coating show diffraction peaks corresponding to the reference steel (ICDD - $\left.\mathrm{N}^{\circ} 00-006-0696\right)$ and probably TiC (ICDD - $\mathrm{N}^{\circ} 00-032-1383$ ). Indeed, we note the presence of a (111) peak at $41.96^{\circ}$, a (200) peak at $48.93^{\circ}$, a (220) peak at $71.78^{\circ}$, a (311) peak at $87.03^{\circ}$, a (222) peak at $91.56^{\circ}$, a $(400)$ peak at $111.55^{\circ}$ and a (311) peak at $128.59^{\circ}$. The detected $\mathrm{TiC}$ phase is a $\mathrm{NaCl}$ face-centered-cubic like structure. Using Bragg's law [19], the experimental lattice parameter calculated from the diffraction peak of $\mathrm{TiC}$ is equal to $0.432 \mathrm{~nm}$, which is consistent with the average theoretical lattice parameter $\left(\mathrm{a}_{\mathrm{TiC}}=0.4327 \mathrm{~nm}\right)[17]$.

Most of the TiWCN coatings delaminate probably because of the formation of high residual stress.

\subsection{Coefficient of Friction (COF) and wear mechanisms}

\subsubsection{Tests with a $100 \mathrm{Cr} 6$ ball}

The friction curve of the reference steel can be decomposed into three parts. First, a break where there is a high decrease of the friction coefficient from 0.7 to 0.55 over a very short period $(<10 \mathrm{~m})$ due to the contaminated nature of the surface, i.e. 'surface pollution' [7]. Then, we observed a slight increase of the COF from 0.55 to 0.65 during the next $55 \mathrm{~m}$ before a short drop to 0.75 on $10 \mathrm{~m}$. During the last $120 \mathrm{~m}$ of sliding this value remains constant. The coefficients of friction of the carburized and carbonitrided samples present a slight increase from 0.8 to 0.95 during the complete test after the break-in period of $15 \mathrm{~m}$. This high value is probably due to a heavy atomic interaction between the two opposing surfaces. The friction coefficients of TiWC films on the treated and untreated steel are almost identical, and close to around $0.28-0.3$. Figure 3 shows the wear rates of the samples against the steel ball.

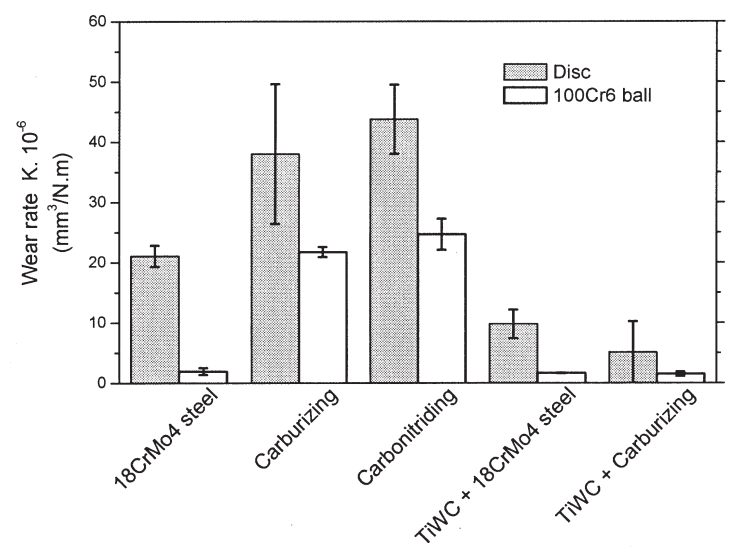

Figure 3. Wear rates of tested samples sliding against a $100 \mathrm{Cr} 6$ ball.

It is found that the wear rate of the reference steel is lower than for a carburized or a carbonitrided sample. We obtained wear rates of $21 \pm 2 \cdot 10^{-6} \mathrm{~mm}^{3} / \mathrm{Nm}, 38 \pm 11.10^{-6} \mathrm{~mm}^{3} / \mathrm{Nm}$ and 
$43 \pm 5.10^{-6} \mathrm{~mm}^{3} / \mathrm{Nm}$ for the reference, carburized and carbonitrided samples respectively. This gap can be explained by the presence of retained austenite in the carburized and carbonitrided layers and strong atomic interactions between the two surfaces. In contrast, TiWC coating has a good resistance to wear. The wear rate of the duplex (carburizing + TiWC) system is approximately twice lower than that of the (reference + TiWC) system. The carburizing of $18 \mathrm{CrMo} 4$ before deposition allows a better adhesion of the TiWC coating.

The wear rate of the $100 \mathrm{Cr} 6$ ball sliding against a treated sample (carburized or carbonitrided) is about two to three times higher than that of the reference steel sample. The wear rate of the ball in contact with duplex treated samples remains very low. The wear and rough appearance of the ball is due to the high values of the ball/disc couple coefficient of friction, while the low wear of the ball in contact with the duplex treated steel is due to their low coefficient of friction.

The wear track profiles reveal that carburized and carbonitrided samples are the most damaged. This is characteristic to both abrasive and adhesive wear mechanisms because of the high coefficient of friction of these treated samples. The depth of the wear track is around 4 and $5 \mu \mathrm{m}$ and presents more scratches and significant amounts of debris that stick to the friction surface. The particular aspect of the wear track of these treated samples can also be due to the heterogeneity of their surface (presence of retained austenite). The TiWC coating, characterized by a low wear depth $(\approx 0.7 \mu \mathrm{m})$ and very small scratches, is slightly worn. Debris was observed at the edges and in the wear track as small grains. The wear of the coating occurs simultaneously by adhesion and abrasion. EDX microanalyses showed that the oxygen content is relatively high in the debris located at the edges and in the wear track, indicating that tribo-oxidation probably occurred.

Based on the above results, TiWC coating deposited on carburized steel presents the best grip, and wear resistance and of course the lowest coefficient of friction.

\subsubsection{Tests with an alumina ball $\left(\mathrm{Al}_{2} \underline{\mathrm{O}}_{3}\right)$}

After a short break-in period $(<2 \mathrm{~m})$, the reference, carburized and carbonitrided steel COF reach a stable value with high dispersion. The average value of the COF is 0.78 for the reference steel sample and varies between 0.85 and 1 for the thermochemically treated steel samples. The TiWC coating is characterized by the lowest and a stable COF ( 0.25 to 0.32$)$ during the test.

Figure 4 shows the wear rates of the samples against the alumina ball.

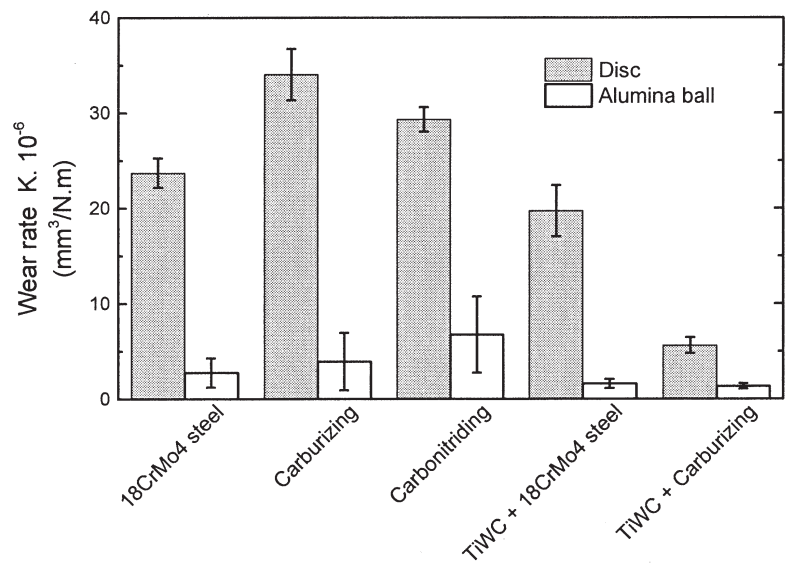

Figure 4. Wear rates of tested samples sliding against an alumina ball. 
The TiWC coating deposited on the reference steel sample is characterized by a high wear rate due to its delamination after only $200 \mathrm{~m}$ of sliding and its poor adhesion. The lowest wear rate is observed for the carburized steel / TiWC coating system that presents the best wear resistance. The wear rate of the TiWC coating deposited on the carburized steel is four times lower than that of the TiWC coating deposited on a reference steel sample; this can be explained by a better adhesion of the coating on the thermochemically treated steel and by the increase of the hardness of the surface.

The worn surface samples show the greatest width and depth of wear and also the presence of debris on their edges. The worn and rough appearance of these sample surfaces and the alumina ball is correlated with their coefficient of friction that justifies their high wear rates. We can conclude that the ball is worn during the transitional period following an abrasive wear mode. However, a similar wear depth was observed for the TiWC coated reference steel sample, which confirms the delamination of the coating. EDX microanalysis shows the presence of aluminium and oxygen in the wear track probably due to oxidation of the steel debris in contact with air.

The TiWC coating / carburized steel system in contact with an $\mathrm{Al}_{2} \mathrm{O}_{3}$ ball exhibits the best tribological behavior thanks to the carburizing of the sample (modification of the chemical composition of the surface and mechanical properties). Besides, the treated steels with a high coefficient of friction and wear rate present a poor tribological behavior.

\section{CONCLUSION}

The objective of this study was focused on the study of the tribological behavior of TiWC carbide layers deposited on carburized steel and of TiWCN on carbonitrided steel. To perform this study, we characterized the properties of the steel treated with the different processes (carburizing and carbonitriding) and of the coatings obtained by RF magnetron sputtering in order to verify the influence of pre-treatment of our steel on the tribological properties.

The carburizing or carbonitriding treatment of $18 \mathrm{CrMo} 4$ steel provides the desired mechanical properties gradient.

The comparative study of the tribological behavior of different systems (couple of materials) leads to the following conclusions:

- Thermochemical treatment (carburizing or carbonitriding) increase the coefficient of friction of $18 \mathrm{CrMo} 4$ steel.

- $\quad$ The presence of retained austenite in the carburized or carbonitrided layer promotes wear in depth and decreases the surface hardness.

- The wear of steel is simultaneously due to adhesion, abrasion and tribo-oxidation while the wear of coatings is simultaneously due to adhesion and abrasion.

- The best tribological performances were observed for the carburizing + TiWC duplex treatment. Indeed, the carburizing of the $18 \mathrm{CrMo} 4$ steel enables a good adhesion of the TiWC coating in comparison to the reference steel.

\section{REFERENCES}

[1] I. Zukerman, A. Raveh, Y. Landau, R. Weiss, R. Shneck, Y. Shneor, Surf. Coat. Technol. 201 (2007) 6171-6175.

[2] M. Bader, H.J. Spies, K. Hock, E. Broszeit, H. J. Schroder, Surf. Coat. Technol. 98 (1998) 891-896.

[3] B. Navinsek, P. Panjan, F. Gorenjak, Surf. Coat. Technol. 137 (2001) 255-264. 
[4] K. Hock, H.J. Spies, B. Larisch, G. Leonhardt, B. Buecken, Surf. Coat. Technol. 88 (1996) 44-49.

[5] J. Smolik, J. Walkowicz, J. Tacikowski, Surf. Coat. Technol. 125 (2000) 134-140.

[6] I. Rahil, Élaboration et caractérisation de revêtements à base de nitrure de Chrome, carbonitrure et carbure de Titane élaborés par pulvérisation magnétron. Arts et Métiers ParisTech, France, 2013.

[7] N.E. Beliardouh, C. Nouveau, M.J. Walock, P. Jacquet, Surf. Coat. Technol. 259 (2014) 483-494.

[8] J.F. Archard, J. Appl. Phys. 24 (1953) 981-988.

[9] K. Genela, M. Demirkol, Int. J. Fatigue 21 (1999) 207-212.

[10] A. Bensely, A. Prabhakaran, D. Mohan Lal, G. Nagarajan, Cryogenics 45 (2006) 747-754.

[11] L. Barrallier, MécaSurf, Genèse des contraintes résiduelles de nitruration: Étude expérimentale et modélisation, Arts et Métiers ParisTech, France, 1992.

[12] F. Haftlanga, A. Habibolahzadeh, M.H. Sohi, Appl. Surf. Sci. 329 (2015) 240-247.

[13] A.F. Rousseau, J.G. Partridge, E.L.H. Mayes, J.T. Toton, M. Kracica, D.G. McCulloch, E.D. Doyle, Surf. Coat. Technol. 272 (2015) 403-408.

[14] F. Bloquel, L. Barrallier, G. Bourse, J. Dürr, J. phys. IV 09 (1996) 211-217.

[15] A.A. Candido Recco, A.P. Tschiptschin, J. Mater. Res. Technol. 1 (3) (2012) 182-188.

[16] D.E. Wolfe, J. Singh, Surf. Coat. Technol. 124 (2000) 142-153.

[17] H.O. Pierson, Handbook of refractory carbides and nitrides, Noyes Publications, USA, 1996.

[18] X. Yin, I. Gotman, L. Klinger, E.Y. Gutmanas, Mater. Sci. and Eng. A 396 (2005) 107114.

[19] W. L. Bragg, Proceedings of the Cambridge Philosophical Society 17 (1913) 43-57. 